\title{
ФОРМИРОВАНИЕ МЕДИЦИНСКОГО ВЫСШЕГО УЧЕБНОГО ЗАВЕДЕНИЯ В ТЮМЕНСКОЙ ОБЛАСТИ
}

\section{FORMATION OF A MEDICAL HIGHER EDUCATION INSTITUTION IN THE TYUMEN REGION}

\section{P. Skripnikov}

Summary: this work is an overview of the formation and development of the system of training doctors in the Tyumen region, starting in the 60 s of the twentieth century. The purpose of the research is to study and analyze the main stages and regularities of the creation of the Tyumen state medical Institute. The region was in dire need of a higher education institution that could train and train specialists who would be able to control the situation for the treatment and prevention of various diseases and pathologies of the constantly growing population. The main method of research was the analysis of secondary sources and documents of the State archive of socio-political history of the Tyumen region and the State archive of the Tyumen region. The key date can be called 03.06.1963, when the Council of Ministers of the USSR approved a resolution on the establishment of the Tyumen medical Institute, which was signed by Deputy Prime Minister A.N. Kosygin. And already in 1969, the first graduation of TSMI doctors took place, and 180 young specialist doctors received treatment and prevention facilities.

Keywords: higher medical education in Siberia, Tyumen state medical Institute, faculty of medicine, state archives, Tyumen region.

\author{
Скрипников Павел Николаевич \\ аспирант, БУ ВО Ханты-Мансийского автономного \\ округа - Югры «Сургутский государственный \\ университет", г. Сургут \\ khoshiminov@inbox.ru
}

Аннотация: Данная работа представляет собой обзор становления и развития системы подготовки врачей в Тюменской области, начиная в 60-х годах XX столетия. Цель исследования - изучить и провести анализ основных этапов и закономерностей создания Тюменского государственного медицинского института. Область остро нуждалась в высшем учебном заведении, способном обучить и подготовить специалистов, которым будет посильно контролировать ситуацию по лечению и профилактике различного рода заболеваний и патологий постоянно возрастающей численности населения. Основным методом исследования послужил анализ вторичных источников и документов Государственного архива социально-политической истории Тюменской области и Государственного архива Тюменской области. Ключевой датой можно назвать 03.06.1963 год, когда Советом Министров СССР было утверждено постановление по учреждению Тюменского мединститута, которое было подписано заместителем председателя правительства А.Н. Косыгиным. И уже в 1969 году состоялся первый выпуск медиков ТГМИ, и лечебно-профилактические учреждения получили 180 молодых врачей-специалистов.

Ключевые слова: высшее медицинское образование Сибири, Тюменский государственный медицинский институт, медицинский факультет, государственные архивы, Тюменская область.
Д ля Тюменской области - жизненно необходимой административно-территориальной единицы РСФСР в экономическом плане, - 1960-е гг. стали 作 на главная топливно-энергетическая база СССР, обеспечивавшая потребности как самой страны, так и зарубежных государств в минеральных ресурсах, используемых в сфере материального производства. Однако изменившейся обстановке в изучаемом регионе не соответствовали ни качество охраны здоровья, ни количество старшего медицинского персонала, т. е. врачей, имеющих должный уровень обучения и подготовки. Область остро нуждалась в высшем учебном заведении, способном обучить и подготовить специалистов, которым будет посильно контролировать ситуацию по лечению и профилактике различного рода заболеваний и патологий постоянно возрастающей численности населения.

В 1961 году Министерство Здравоохранения РСФСР сообщило об открытии за последнее время ряда новых медицинских ВУЗов и факультетов в азиатской части Российской Федерации, что свидетельствовало о воз- можности более равномерного обеспечения сибирских районов врачебными кадрами. Однако увеличение численности медицинских высших учебных заведений опережало возможности создания для них соответствующей материально-технической базы и подготовки квалифицированного преподавательского состава. Сложившаяся ситуация указывала на то, что подавляющее большинство институтов и факультетов РСФСР, прямая задача которых - обучить и подготовить для нужд отечественного здравоохранения врачебные кадры, было обеспечено учебной площадью всего на 48,5\% по отношению к установленным нормативам и общежитиями на 44\% по отношению к потребности. Не без внимания оставался также и вопрос о ряде должностей, заведующих кафедрами и преподавателей, остающихся вакантными из-за невозможности замены лицами соответствующей квалификации. В особенно трудном положении находились медицинские высшие учебные заведения Западной Сибири. Поэтому на текущее семилетие была поставлена важная задача по укреплению материальнотехнической базы существующих институтов и подготовке для них профессорско-преподавательских кадров. 
Однако открытие медицинского высшего учебного заведения в административном центре Тюменской области в ближайшие семь лет не предусматривалось несмотря на ходатайство со стороны Исполнительного комитета Тюменского областного Совета депутатов трудящихся. Министерство здравоохранения РСФСР объясняло это тем, что подобное решение неминуемо повлекло бы за собой дальнейшее ухудшение условий работы уже существующих медицинских институтов и вызвало бы неминуемое распыление средств и преподавательского состава [4].

Необходимо заметить немаловажное обстоятельство: еще до основания Тюменского государственного медицинского института, а именно на 01.01.1963 г. в Тюменской области работало 1350 врачей. А за пять лет до этого, т.е. в 1958 году число специалистов с высшим медицинским образованием составляло 1046 человек. Сопоставляя данные цифры, выходит, что рост численности старшего медицинского персонала (в 1,29 раза) свидетельствовал об острой необходимости создания в центре наибольшей административно-территориальной единицы Западной Сибири высшего учебного заведения, готовящего врачебные кадры, в будущем трудящиеся на благо социальной сферы [5].

Однако у Правительства страны было на этот счет свое мнение. Административный центр Тюменской области считали малозначительным для организации в нем медицинского института. Ярким свидетельством этому является мнение министра здравоохранения СССР С.В. Курашова, высказанное первому секретарю Тюменского промышленного обкома КПСС А.К. Протозанову во время телефонного разговора. Рекомендация высшему партийному органу регионального управления была простой, но в то же время эффективной: молодежь, твердо решившую посвятить свою жизнь предупреждению и лечению заболеваний, а также поддержанию нормальной жизнедеятельности организма человека, необходимо направлять на учебу в такие города, имеющие медицинские высшие учебные заведения, как Омск, Свердловск и Челябинск.

Однако при всем уважении к тов. Курашову следует признать неоспоримый факт: руководство Тюменского обкома КПСС как нельзя лучше понимало огромные перспективы, которые открывались перед областью в связи с освоением и разработкой ЗСНГК и хорошо представляло необходимость развития социальной сферы. Оно также полагало, что обеспечение специалистами в области здравоохранения должно осуществляться в весьма значительной мере за счет выпускников медицинских ВУЗов [1].

03.03.1963 года высшим партийным органом управления Тюменской областью, а именно обкомом КПСС, было отправлено письмо в Совет Министров СССР, не только информирующее о наличии и количестве ми- неральных ресурсов, строительстве новых железных дорог и заводов, развитии нефтегазодобывающей промышленности и быстро растущем населении, но и ясно и четко обосновывающее необходимость создания в области медицинского высшего учебного заведения. Однако главным был факт сдерживания развития медобслуживания из-за острого недостатка врачей. Существовавшая сеть лечебно-профилактических учреждений не была укомплектована. Вследствие этого обстоятельства из 2522 штатных врачебных должностей не было замещено 1 147. Данным фактом можно объяснить закрытие в лесной промышленности 58 врачебных участков. Амбулатории, консультации и поликлиники имели большую перегрузку старшего медицинского персонала, отрицательно сказывавшуюся на качестве его деятельности по лечению и профилактике, что в свою очередь вызывало многочисленные жалобы и нарекания трудящихся. Определенные трудности также создавала большая текучесть кадров вследствие отъезда из Тюменской области молодых специалистов, а именно через год-два, приехавших на работу после окончания медицинских институтов, расположенных в центральных и южных районах СССР. Количество выбывших врачей в период с 1958 по 1963 гг. составляло 1062 человека. Общая эпидемиологическая обстановка на территории Тюменской области оставалась весьма неблагополучной в связи с высоким уровнем заболеваемости и смертности от брюшного тифа, дизентерии и дифтерии. Наличие в составе изучаемой административно-территориальной единицы РСФСР Ханты-Мансийского и Ямало-Ненецкого округов обязывало органы охраны здоровья учесть специфику этих субъектов, условия жизни и обычаи коренных малочисленных народов Севера, а также решить нюансы по обучению и подготовке национальных врачебных кадров. Острый недостаток специалистов с высшим медицинским образованием в условиях быстрого развития экономики и роста населения Тюменской области вызвал необходимость решения вопроса об открытии в административном центре изучаемого субъекта РСФСР медицинского института [1].

Заведующий Тюменским облздравотделом Ю.Н. Семовских вспоминал, как они с главным врачом областной больницы А.А. Моисеенко поехали в Москву и почти три месяца договаривались с Госпланом, Министерствами здравоохранения, высшего и среднего образования, финансов, обороны об открытии медицинского института. Секретарь Тюменского обкома КПСС А.К. Протозанов, являвшийся инициатором создания нового ВУЗа, лично участвовал в этих переговорах [7].

Примечателен так же факт того, что дирекция Омского медицинского института посчитала возможным не только поставить вопрос перед Министерством здравоохранения об организации в Тюмени ВУЗа для обучения и подготовки старшего медицинского персонала в основном из представителей коренных малочислен- 
ных народов Севера. В случае положительного решения Тюменскому облисполкому была бы на первых стадиях создания института обещана не только необходимая методическая и организационная помощь, но также заблаговременная подготовка будущих ассистентов по анатомии, физике, химии и руководство научно-исследовательскими работами. Не следует упускать из виду и факт того, что имеющийся при медицинском ВУЗе Омска интернат для детей Севера мог быть передан Тюмени в любое время в качестве базы для будущих студентов [3].

03.06.1963 года Совет Министров СССР утвердил постановление по учреждению Тюменского мединститута. Это постановление подписал заместитель председателя правительства А.Н. Косыгин, который еще в 1924-1926 гг. работал в Тюмени инструктором городского отдела потребительской кооперации [11].

08. 06. 1963 года Совет Министров РСФСР отдал распоряжение №2336 об учреждении в 1963 году Тюменского медицинского института с установленным планом приема студентов в количестве 300 человек [13].

21.06.1963 г. министр здравоохранения РСФСР В.В. Трофимов подписал приказ №212, назначавший ректором в порядке перевода из Свердловского мединститута кандидата медицинских наук Е.А. Жукова [12].

В процессе становления ВУЗа была оказана систематическая поддержка Тюменского обкома КПСС в осуществлении строительных работ, в приобретении оборудования, мебели, специфического лабораторного хозяйства, огромную помощь оказали промышленные предприятия, строительные организации и представители нефтегазового комплекса, лечебно-профилактические учреждения Тюмени и районов. Всеобщая ак- тивность дала возможность 4 октября 1963 года начать учебный процесс в Тюменском государственном медицинском институте [10, с. 289].

Изначально в ВУЗе существовал один лечебный факультет и девять кафедр. Начавшие функционировать виварий, экспериментальная операционная, рентгеновский кабинет, фотолаборатория являлись фундаментом для научно-исследовательской работы. При областной и городской больницах были созданы клинические кафедры медицинского института. В 1964 году открылся и второй факультет - фармацевтический.

Участие авторитетных ученых страны в становлении ТГМИ помогло нарастить научно-исследовательский потенциал и сформировать профессорско-преподавательский состав в соответствии с директивами союзного и республиканского Минздравов. С 1963 по 1969 гг. был издан первый сборник научных трудов, опубликовано свыше 100 научных статей и материалов, написано и защищено 37 кандидатских и 13 докторских диссертаций [7].

В 1969 году состоялся первый выпуск медиков ТГМИ, и лечебно-профилактические учреждения получили 180 молодых врачей-специалистов [6].

В числе прочих первые дипломы провизора вручили двум выпускницам из числа жителей коренной народности Тюменского Севера [7].

Таким образом, учреждение медицинского высшего учебного заведения в Тюмени в дальнейшем позволило решить проблему относительно острого недостатка врачебных кадров в условиях быстрого развития экономики и роста населения северных районов.

\section{ЛИТЕРАТУРА}

1. ББут0 «Государственный архив социально-политической истории Тюменской области». Ф. 124. Оп. 1. Д. 5258. Л. 7.

2. ГБУТО «Государственный архив социально-политической истории Тюменской области». Ф. 2010. 0п. 1. Д. 84. Л. 11-15.

3. ГБУТ0 «Государственный архив Тюменской области». Ф Р-814. Оп. 1. Д. 2279. Л. 199

4. ГБУТ0 «Государственный архив Тюменской области». Ф Р-814. Оп. 1. Д. 2433 Л. 123

5. ГБУТ0 «Государственный архив Тюменской области». Ф Р-814. Оп. 1. Д. 3932 Л. 75

6. ГБУТО «Государственный архив Тюменской области». Ф. 1725. 0п. 1. Д. 710. Л. 43.

7. ГБУТ0 «Государственный архив Тюменской области». Ф. 2004. 0п. 1. Д. 3. Л. 2.

8. ГБУТО «Государственный архив Тюменской области». Ф. 2004. Оп. 1. Д. 3. Л. 303-310.

9. ГБУТО «Государственный архив Тюменской области». Ф. 2005. Оп. 1. Д. З. Л. 241.

10. Жаров Л., Ермакова С. Ректоры Тюменской области. С. 289.

11. Постановление Совета Министров СССР № 610 от 03.06 .1963 г. «06 организации Тюменского медицинского института» // ГБУт0 «Государственный архив социально-политической истории Тюменской области». Ф. 2010. 0. 1. Д. 80. Л. 2.

12. Приказ Министра здравоохранения РСФСР № 212 от 21.06.1963 г. «0б организации Тюменского медицинского института» // ГБУТО «Государственный архив Тюменской области». Ф. 2004. 0. 1.Д. З.Л. 4.

13. Распоряжение № 2336 от 08.06.1963 г. «0б организации Тюменского медицинского института» // ГАСПИТО. Ф. 2010. 0. 1. Д. 77. Л. 107.

( ) Скрипников Павел Николаевич (khoshiminov@inbox.ru).

Журнал «Современная наука: актуальные проблемы теории и практики» 